\title{
Financial Inclusion, GDP and Credit Risk of Commercial Banks in Kenya
}

\author{
Salome Musau ${ }^{1}$, Stephen Muathe ${ }^{1} \&$ Lucy Mwangi ${ }^{1}$ \\ ${ }^{1}$ School of Business, Kenyatta University, Kenya \\ Correspondence: Salome Musau, School of Business, Kenyatta University, Kenya. E-mail: \\ musau.salome@ku.ac.ke \\ Received: December 11, 2017 \\ Accepted: February 7, $2018 \quad$ Online Published: February 20, 2018 \\ doi:10.5539/ijef.v10n3p181 \\ URL: https://doi.org/10.5539/ijef.v10n3p181
}

\begin{abstract}
This paper provides an empirical analysis of the synergies and trade-offs between financial inclusion and credit risk of commercial banks in Kenya. The paper analyzed the effect of financial inclusion on credit risk and the moderation effect of GDP on commercial banks in Kenya. Financial inclusion was measured using three dimensions of bank availability, bank accessibility and bank usage, while credit risk was represented by the non performing loans ratio. The study was anchored on financial intermediation theory supported by finance growth theory and asymmetry information theory. The target population was all the 43 commercial banks in Kenya. The study used secondary data collected from Central Bank of Kenya annual reports; commercial banks of Kenya published audited financial statements and annual data from Central Bureau of statistics of Kenya for the period between 2007-2015. Data was analyzed using descriptive statistics and panel multiple regression analysis. The results obtained found that bank availability, bank accessibility and bank usage had significant effect on credit risk of commercial banks in Kenya. GDP growth rate was found to partially moderate the relationship between financial inclusion and credit risk. From the findings the study concluded that financial inclusion has a significant effect on credit risk of commercial banks in Kenya. The study also recommended that commercial banks in Kenya to negotiate with Central Bank and the Ministry of Finance to put policies which support favorable macroeconomic variables especially GDP which influences the level of financial inclusion and bank credit risk.
\end{abstract}

Keywords: financial inclusion, GDP growth rate, credit risk, Kenya

\section{Introduction}

Commercial banks are important financial intermediaries in the economy who perform the basic functions of accepting deposits, lending the money and offering transfer services. The commercial banks also represent a vital link in the transmission of government's economic policies particularly monetary policy to the rest of the economy (Ongore\& Kusa, 2013). In emerging market economies like Kenya, commercial banks remain the dominant channel of financial intermediation. Bank deposits represent the most significant component of money supply used by the public and changes in money growth are highly correlated with changes in prices of goods and services in the economy. For commercial banks to efficiently perform their intermediation role of providing liquidity, they must be stable. Bank stability has been a key international agenda by policy makers since the Global Financial Crisis of 2007-2009. The financial Stability Board and Basel Accord have been key in enhancing financial stability. For Kenya one of the mandate of the Central Bank is to foster financial stability through regulation. The CBK has ensured stability by adopting the Basel II Accord and ensuring compliance by the commercial banks.

\subsection{Financial Inclusion}

According to the Global Partnership of Financial Inclusion (GPFI) and G-20, financial inclusion has become an important component of financial development in the word. Increasing access of financial services to many citizens has been a priority to policy makers. The last decade has witnessed many initiatives by both emerging and developing economies in pushing the financial inclusion agenda. (Demirguc-Kunt et al., 2015). Multilateral agencies including the IMF, G20, the Alliance for Financial Inclusion (AFI), and the Consultative Group to Assist the poor (CGAP) have also been active to enhance the inclusive banking agenda. 
The global financial crisis (GFC) of 2007-2009 put to test the rational of financial inclusion when bank failures were associated with financial inclusion (Carneiro \& Ghosh, 2008). Financial inclusion has also been linked to improved financial performance (Allen et al., 2012). Despite all the importance and renewed attention on financial inclusion and the claim that the GFC was accelerated by financial inclusion, there is still lack of empirical evidence to bring this to conclusion. Besides not much is known on the effect of financial inclusion at the micro level or bank level as most studies are carried out at the sector level with a few studies dealing with individual banks (Allen et al., 2012).

Financial inclusion can be measured using three dimensions, namely availability, accessibility and usage. The availability dimension is used to account for the pervasiveness of outreach of the financial sector in terms of banks' physical outlets, as physical distance to physical point of financial services deems to be an important impediment to financial inclusion (Allen et al., 2014). Availability of banking services was represented in terms of penetration of bank branches, ATMs, and Agents (Mostak \& Sushanta, 2015). For the accessibility the number of bank deposit, loan and mobile accounts per 1000 adult population was used to integrate the depth of the financial access. The usage dimension included the volume of credits plus deposits relative to the GDP (Beck et al., 2014)

This study used the index of financial inclusion (IFI) developed by Sarma and Pias (2011). The index captures information on the three financial inclusion dimensions in a single number lying between $0-1$, where 0 denotes complete financial exclusion and 1 indicates complete financial inclusion. Currently commercial banks are actively targeting groups previously targeted by MFI and previously referred to as unbankable (Allen et al., 2012) under a phenomenon known as downscaling (Delfiner \& Peron, 2007). Chiba (2009) observed that commercial banks have taken action to address financial inclusion by designing new services and products targeting the low-wage earners and the poor throughout the world.

\subsection{Financial Inclusion and Credit Risk}

Loans (Asset quality) are the major assets of commercial banks and their most important single and largest source of income. The quality of loan portfolio determines the profitability of banks (Ongoro \& Kusa, 2013). The highest risk facing a bank is the losses derived from delinquent loans. Delis et al. (2014) observed that NPL ratio is the best to measure credit risk exposure. A major concern of all commercial banks is to keep the amount of NLP low as this is indicative of good health of the bank portfolio and high level of NPL affects profitability negatively. NPL is computed as the ratio of the volume of non-performing loans to total loans of a bank. A default occurs when the bank considers that a borrower is unlikely to repay his credit obligations in full, without recourse to collateral (Morgan \& Poutines,2014).

Increasing financial access through financial inclusion changes the composition of the customers in terms of saving and borrowing behavior. These compositional changes may support financial stability through risk diversification (Hannings \& Jansen, 2010). However, if financial inclusion is expanded to unfamiliar areas and uncreditworthy clients through financial inclusion, this poses an increase in credit risk and hence a threat to stability. Mohrotra and Yetman, 2014 observed that financial stability can enhance trust in the financial system and therefore improving financial inclusion. Conversely, excessive emphasis on financial stability can prolong involuntary financial exclusion. Especially in times of regulatory tightening in an attempt to boost profits and cut off risky segment.

\subsection{Gross Domestic Product}

Macroeconomic policy, gross domestic product, inflation and interest rates are indicators of the overall state of a countries economy. They influence the extent to which nations citizens utilize the financial sector. More favourable macroeconomic conditions are expected to increase the financial inclusion of a population. Higher incomes allow for higher levels of savings which in turn are likely to be held in financial accounts (Adusei, 2015).

This study used macroeconomic variable namely GDP to represent economic development and business cycle of the economy in Kenya while examining the implication of financial inclusion on bank stability. Honohan (2008) observed that economic development generally coincides with an increase in financial inclusion and hence it would be interesting to see whether the impact of financial inclusion remains significant after controlling for GDP and inflation

Kosmidou (2008) found that GDP growth enhances profitability which in turn enhances stability. This is due to the fact that increase in GDP is associated with a general improvement in income in an economy and hence increase in financial inclusion. However, Tan and Floros (2012) observed that growth in GDP may lead to a 
reduction in profitability which by extension affects stability negatively. This was informed by the fact that an improvement in economic growth leads to a conducive environment and lowers bank entry barrier and hence increased competition. The increased competition in the banking sector reduces bank profitability which also implies reduction in stability. From the foregoing study it is clear that the effect of GDP on the financial inclusion and bank stability is inconclusive

\subsection{Commercial Banks in Kenya}

Kenya's Vision 2030 economic blueprint aims to transform Kenya into a middle-income country that provides high quality of life to its citizens by improving access and deepening of financial services and products (Republic of Kenya, 2007). Commercial Banks play key part in economic growth of any country and are usually recognized for their contribution to the monetary operations, employment, innovation and wealth creation of a nation (Ongore \& Kusa, 2013; CBK, 2015).

To achieve this, the Government of Kenya thorough CBK has provided an enabling environment, supporting legal and regulatory framework like the banking amendment Act (2012) which increased the minimum core capital from Ksh 1 billion to Ksh 5 billion in a bid to improve the financial stability of banks, the amendment Act (2015) to cap the commercial bank lending rates at not more than $4 \%$ above the CBR. This was to ensure that commercial banks continue providing financial access and contribute towards realization of vision 2030 prosperous economy.

Commercial banks in Kenya responded to the initiative by opening doors and developed products and services for the previously unbanked population. Over the last ten years bank branches have increased and have embraced the financial sector innovations including ATMs, M-Pesa, M-Shwari, Agency banking, Islamic banking and Mobile banking. According to CBK and FSD Kenya 2015, Financial innovations have led to increased financial inclusion for those groups which were financially excluded before the Kenya's vision 2030 came into implementation.

Despite these initiatives by the government and banks, commercial banks have presented mixed results in terms of their financial stability. In 2015 CBK warned that commercial banks were facing challenges including; fraudulent loans, inadequate provisions for bad loans, capital inadequacy and low cash ratio which have eroded the market confidence in the banking sector (CBK, 2015).

In response, CBK put all banks operating in Kenya under tight scrutiny as it moved to ensure market confidence following the collapse of Charter House Bank, Imperial Bank and Dubai Bank which were put under receivership in 2015. Chase Bank currently is also facing liquidity troubles and challenges of being put under receivership (CBK, 2016). CBK further intensified its supervision efforts and demanded commercial banks to reclassify some of their loans and increase provisioning for credit losses (CBK, 2015).

It is against this background that this study sought to establish the effect of financial inclusion on the credit risk of commercial banks in Kenya. In addition, it also investigated the moderation effect of GDP growth rate on the relationship between financial inclusion and credit risk of commercial banks in Kenya

\section{Literature Review}

\subsection{Theoretical Literature}

The connection between financial inclusion can be understood in the context of the finance growth theory. The crux of the finance growth theory (Bagehot, 1973) is that financial inclusion creates a productive environment for economic growth. This theory supports financial stability which is a condition where the financial intermediation process functions smoothly. And according to Spatt (2013), the success of economic growth depends on the level of financial inclusion, composition and stability of the financial institutions. Thus the existence of an energetic financial sector has growth enhancing effects. Schumpter (1911) posted that banks enable an economy to grow by providing efficient markets for funds. Goldsmith (1969), Mckinnon (1973), Levin and Zervos (1996) emphasized the positive role of financial systems in economic growth as cited by Ndebbio (2004). Financial markets evolve in response to increased demand for financial services from an already budding economy. Therefore, the deepening of financial inclusion is a reflection of growth in other sectors of the economy and for financial institutions to support financial inclusion, they must be financially stable.

Another theory which offers an explanation for the possible relationship between financial inclusion and bank credit risk is the financial intermediation theory. The theory by Diamond in 1984 explains how banks act as intermediaries between borrowers and savers. As financial intermediaries, banks provide access, financial diversification and financial utilization. The extent of inclusion has an influence on the level of stability as confirmed by literature. Financial intermediation is seen as the extent to which financial institutions bring deficit 
spending units and surplus spending units together (Ndebbio, 2004). Diamond (1984) pointed out that banks are able to effectively monitor borrowers and thus play the role of delegated monitoring. Reduced monitoring costs are a source of comparative advantage. Diamond and Dybrig (1983) analyzed the position of liquidity that is transformation of illiquid assets into liquid liabilities by banks. In their model, identical investors or depositors are risk averse and uncertain about the timely of their future consumption need. Without an intermediary all investors are locked into illiquid long term investments that yield high pay offs to those who consume later.

The effect of financial inclusion on bank credit risk can also be viewed from the perspective of the financial asymmetry theory. Information asymmetry arises where one party in a debt contract has more and better information than the other party. The theory was proposed by Akerlof in 1970 and observes that it may be difficult to distinguish good from bad borrowers. According to Richard (2011) moral hazard and adverse selection results from information asymmetry between borrowers and lenders can contribute to contractions in credit hence affecting performance and stability. Moral hazard is the risk which a party to a transaction provides misleading information about its assets, liabilities or credit capacity. This is noted to be contributing to Non-Performing Loans.

Adverse selection assumes that lenders cannot distinguish between borrowers of different degrees of risk and that loan contracts are limited. This leads to borrowers repaying loans when they have the means to do so, and hence significant accumulation of Non-Performing Loans (Bofondi \& Gobbi, 2003). Financial Inclusion is characterized by entry of new, inexperienced and numerous customers into the formal financial sector including Commercial Banks (Hansen \& Jansen, 2010). This creates a challenge in the debt market because lenders have difficulties in determining whether the customer is a good risk and this threatens financial performance and hence stability. Therefore it becomes difficult for banks to establish whether financial inclusion is a low risk good investment or otherwise.

\subsection{Empirical Review}

For the banks to fully appreciate the concept of financial inclusion there is need to understand its effect on the banks that engage in it. This is because financial inclusion clientele are considered opaque, numerous and characterized by frequent small value transactions with high operating costs (Hannig\& Jansen, 2010) and this can pose potential threat to stability. According to Kipesha and Zhang (2013) financial inclusion in Kenya and other developing countries was previously spearheaded by MFI's and government owned banks. However, currently commercial banks which are mainly profit seeking have engaged in financial inclusion. Due to the change in financial inclusion landscape by commercial banks, it's important to understand its implication on their stability.

Most of the early studies are carried out at the sector level with a few studies dealing with individual banks (Hanning \& Johnson, 2010; Han \& Maleck, 2013; Morgan \& Poritiness, 2014; Mostak \& Sushanta, 2015; Amatus \& Alireza, 2015). These studies established that increased financial inclusion improves asset quality of the banking sector. However, other studies have revealed potential threats caused by financial inclusion. Lending to those previously excluded from the formal banking sector in India revealed that new customers were not credit worthy and were a threat to banks stability (Gokhale, 2009; Allen et al., 2012; Khan, 2011). This has created two divergent schools of thought with one claiming the financial inclusion-stability effect and the other claiming financial inclusion-instability outcome. Another stand of research posits that financial inclusion and financial stability have a relationship and that synergies between the two exist (Adasme et al., 2008; Cihaki et al., 2015). The foregoing studies confirm that there exists an empirical gap in the area of financial inclusion and stability at micro level as opposed to macro level. This study aims at enriching the existing related literature by studying the relationship between financial inclusion and stability of commercial banks in Kenya.

Based on the above literature this study sought to interrogate how financial inclusion affects the credit risk of commercial banks. $\mathrm{H}_{01}$ : Bank availability has no significant effect on the credit risk of commercial banks in Kenya. Bank availability was measured using the number of Branch networks, ATMs and Bank Agents, $\mathrm{H}_{02}$ : Bank accessibility has no significant effect on the credit risk of commercial banks in Kenya. Bank accessibility was measured using deposit, loan and mobile accounts. $\mathrm{H}_{03}$ : Bank usage has no significant effect on the credit risk of commercial banks in Kenya. Bank usage was measured using total deposit/GDP and total loan/GDP. Credit risk was measured using non performing loans ratio.

\subsubsection{Financial Inclusion, GDP Growth Rate and Credit Risk}

Honohan (2008), observed that GDP is an important determinants of financial inclusion and bank stability. He posited that as economic development increases also financial inclusion increases in equal measures. In this study, GDP was used to measure the changes in macroeconomic stability as well as the overall economic performance in 
Kenyan during the study period. Earlier, a number of studies have been carried out to establish the effect of macroeconomic factors on bank stability and have revealed mixed effects with some proposing a negative effect while others a positive effect.

Kosmidou (2008) established GDP growth as profit enhancing which in turn enhances bank stability. This is due to the fact that increase in GDP growth rate is associated with better economic performance in a country. Contrary, Tan and Floros (2012) suggest that growth in GDP leads to a reduction in profitability and by extension a reduction in bank stability. They argue that an improvement in economic growth results in an improvement in the business environment and lowers entry barrier. This promotes competition which reduces bank profitability implying a reduction in stability. From the foregoing studies, the effect of GDP on bank stability is inconclusive. Hence the study tested the following hypothesis $\mathrm{HO}_{4}$ : There is no significant moderation effect of GDP growth rate on the relationship between financial inclusion and Credit Risk of commercial banks in Kenya.

\section{Research Methodology}

This research employed both descriptive and explanatory none experimental research designs. The descriptive research design was chosen because of its suitability in describing the characteristics of a particular individual, or a group of individuals since the researcher did not have control over the variables. The descriptive design affords the researcher an opportunity to capture a population's characteristic and test hypothesis (Cooper \& Schindler, 2008). The population for this study was comprised of the 43 commercial banks in Kenya .Secondary data was obtained from banks annual financial statements, bank supervision reports by CBK and Kenya Bureau of Statistics for the period between 2007 and 2015.

\subsection{Empirical Model}

In this study, the dependent variable was continuous, so panel multiple regressions model was used. Multivariate analysis was used to perform regression on the relationships between the various variables so as to understand the strength of each predictor variable. The general empirical model that was used in this study is adapted from Mostak and Sushanta (2015) and Beck et al. (2009). However whereas they based their analysis on a cross country panel data set, this study was based on commercial banks in Kenya and the following models where estimated. The moderation effect model was borrowed from Baron and Kenny (1986).

$$
\begin{array}{cc}
\text { Credit } \text { Risk }_{i t}=\alpha+\beta_{1} B A V_{i t}+\beta_{2} B A C_{i t}+\beta_{3} B U S_{i t}+\varepsilon_{i t} & \text { Model } 1 \\
\text { Credit Risk }{ }_{i t}=\alpha+\beta_{I} I F I_{i t}+\varepsilon_{i t} & \text { Model } 2 \\
\text { Credit Risk }_{i t}=\alpha+\beta_{1} I F I_{i t}+\beta_{2} G D P_{i t}+\varepsilon_{i t} & \text { Model } 3 \\
\text { Credit Risk } k_{i t}=\alpha+\beta_{I} I F I_{i t}+\beta_{2} G D P_{i t}+\beta_{3} I F I^{*} G D P_{i t}+\varepsilon_{i t} & \text { Model } 4
\end{array}
$$

Where:

Credit Risk $_{\mathrm{it}}=$ The level of exposure to Credit risk for bank ${ }_{\mathrm{i}}$ at time $\mathrm{t}$

$\mathrm{BAV}_{\text {it }}=$ Bank availability of bank $\mathrm{i}$ at time $\mathrm{t}$

$\mathrm{BAC}_{\mathrm{it}}=$ Bank accessibility of bank $\mathrm{i}$ at time $\mathrm{t}$

BUS $_{\text {it }}=$ Bank usage of bank $\mathrm{i}$ at time $\mathrm{t}$

$\mathrm{IFI}_{\mathrm{it}}=\mathrm{A}$ composite Index of Financial Inclusion for bank $\mathrm{i}$ at time $\mathrm{t}$

$\mathrm{GDP}_{\mathrm{it}}=\mathrm{GDP}$ growth rate of bank $\mathrm{i}$ at time $\mathrm{t}$

$\alpha=$ Constant term

$\beta_{\mathrm{s}}=$ Coefficients of the explanatory variables

$\varepsilon_{\text {it }}=$ Error term

\section{Presentation and Interpretation of Results}

The results of the analysis are presented as follows; Descriptive trend analysis, Diagnostic checks and panels multiple regressions.

\subsection{Descriptive Results}

\subsubsection{Trends in Financial Inclusion}

Figure 1 presents the trend analysis of financial inclusion variables measured using bank availability, bank accessibility (BAC), bank usage (BUS) and an overall financial inclusion index (IFI). This study used the index of financial inclusion (IFI) developed by Sarma and Pias (2011). The index captures information on the three 
financial inclusion dimensions in a single number lying between $0-1$, where 0 denotes complete financial exclusion and 1 indicates complete financial inclusion.

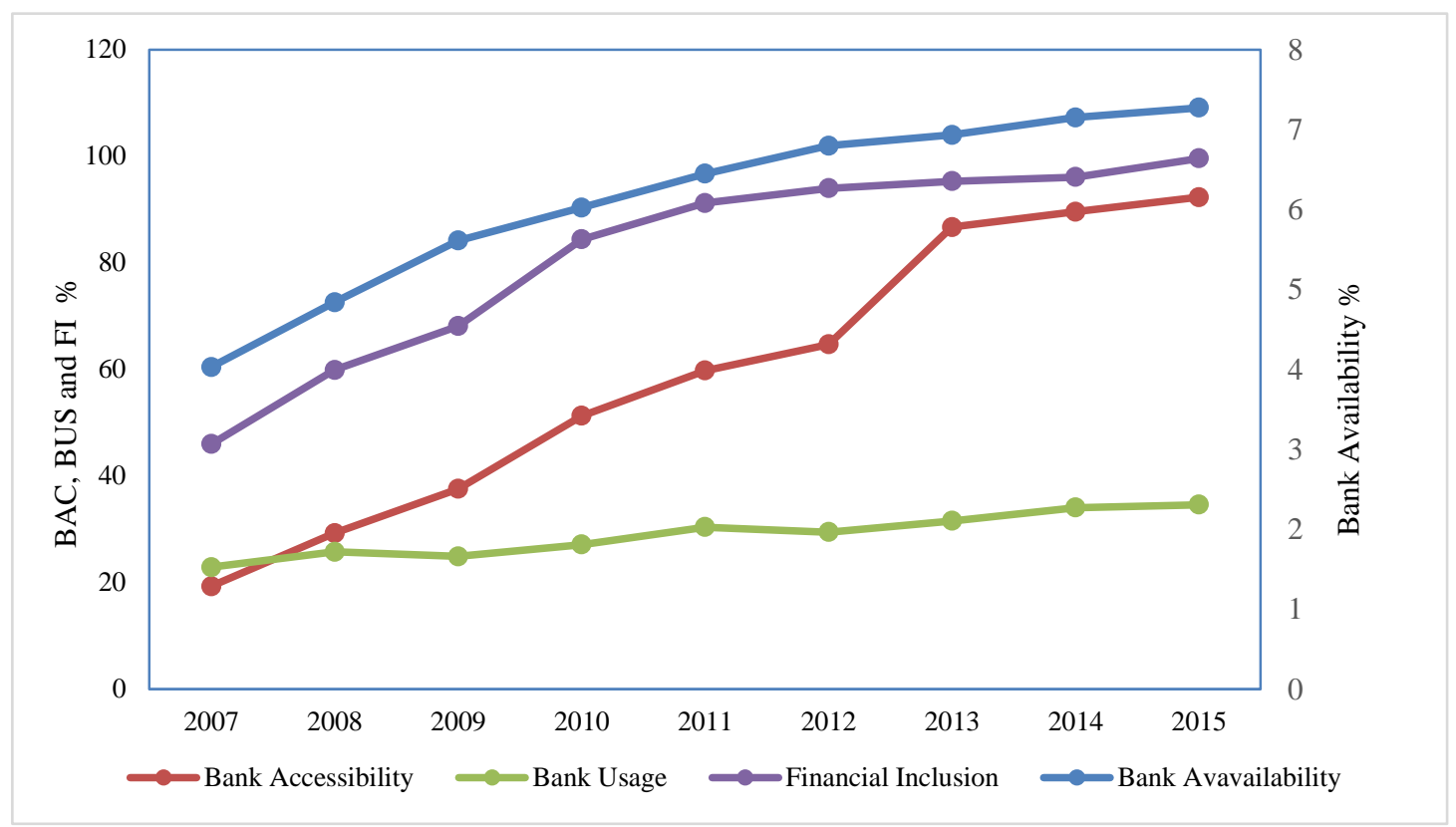

Figure 1. Trend in financial inclusion

Source of Data: CBK annual Reports.

Overall with respect to financial inclusion Figure 2 shows that all the measures of financial inclusion had an upward trend in the entire study period. Bank availability was measured using a composite index comprising of the number of ATMs and bank branches per 100 people. Being the primary means of accessibility bank branches was assigned a weight of two thirds while ATMs were assigned a third. The weighted average of the bank branches, ATMs and agents yielded the composite index of bank availability. A value of zero would imply no availability at all while a value of 100 would mean perfect availability. Figure 1 shows that the index rose consistently during the study period to stand at eight. At the beginning of the study period the index stood at four percent. Comparing this figure to eight percent at the end of the period means that on average commercial bank availability doubled during the study period. Therefore, commercial banks customers had more variety in obtaining banking services bank with respect to branches and ATMs.

On the hand bank accessibility was proxied by the number of bank accounts per 100 people. A value of zero implies no accessibility at all while a value of 100 shows perfect accessibility. Figure 1 shows that bank accessibility rose rapidly from 19 accounts at the beginning of the study period to 92 accounts per 100 people. This implies that bank accessibility more than quadrupled during the study period. This means that the population of Kenyans with bank accounts more than quadrupled between 2007 and 2015. The holding of bank accounts by 92 persons per 100 people means that commercial banks accessibility in enya can be considered near perfect. This is supported by a report by FSD Kenya in 2016 which placed Kenya to be above $70 \%$ in financial inclusion.

Banks usage was measured by the ratio of lending to the private sector. This component measures those who are able to access commercial banks and use their services. A value of zero would mean no usage at all while a value of 100 would imply perfect usage. Figure 1 shows that bank usage grew from 23 to 34 per cent during the entire study period. The 11 percentage points are meager compared to the other domains of financial inclusion. This means that though a lot of people are able to access commercial banks through bank accounts only a small fraction is able to make use of the commercial banks' lending opportunities. Therefore, commercial banking in Kenya is accessible but not largely usable.

The overall Index of financial inclusion was obtained using the formula suggested by Sarma (2008). The index ranged from zero to 100 percent. A value of zero would imply imperfect inclusion while that of 100 implies 
perfect inclusion. Figure 2 shows that the index raised from 46 to 99.6 during the study period. This implied that in general financial inclusion in Kenya is nearing a perfect state and this is also supported by FSD report 2016 which placed Kenya to be above $75 \%$ in financial inclusion.

\subsubsection{Trends in GDP Growth Rates}

Kenya economic growth has been very erratic as a result of many factors among them political environment. The results showed that there was a sharp drop in GDP growth rate in 2008 probably due to post-election violence. From 2008, the country has seen resurgent of the economy to almost a double digit growth in 2010.

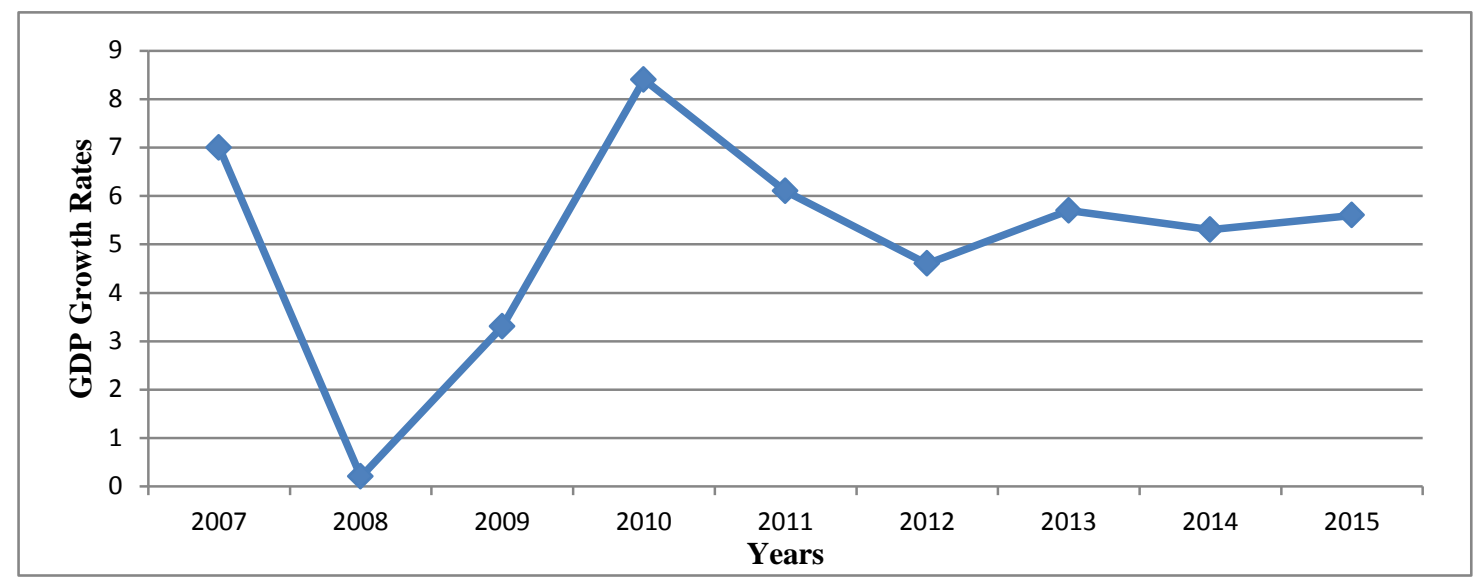

Figure 2. Trends in GDP growth rates between 2007 and 2015

Source: Research Data, 2017.

\subsubsection{Bank Credit Risk}

This section contains descriptive results for bank credit risk measured by non performing loans ratio as measures of commercial bank stability.

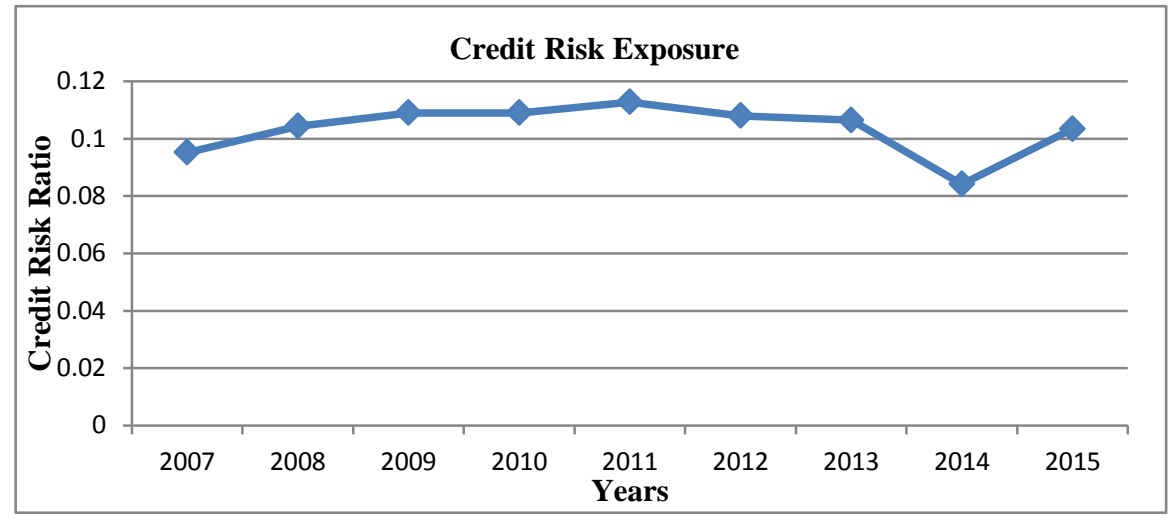

Figure 3. Trends in credit risk between 2007 and 2015

The findings in Figure 3 showed constant credit risk exposure with a slight drop in 2014. This implied that commercial banks exopsure to credit risk minimum in 2014. The finding showed that exposure to credit risk increased in 2015 which coincided with the collapse of a number of commercial banks in Kenya.

\subsection{Diagnostic Checks}

The study performed tests on statistical assumptions i.e. test of regression assumption and statistic used. This included test of normality, heteroskedasticity, multicollinearity, autocorrelation, panel unit root test and Hausman test for model specification. The tests were conducted to make sure that the statistical analysis conducted adhered to regression assumption hence avoid spurious and bias findings. 


\subsubsection{Normality Test}

The normality test was conducted using the Jarque-Bera (JB) and normality graph. The results in the figure indicate that the residuals were normally distributed. To further establish whether the residuals were normally distributed the study adopted the Jarque-Bera test which is a more conclusive test than the graphical inspection approach of testing for normality. The results of the Jarque-Bera test are shown in Figure 4.
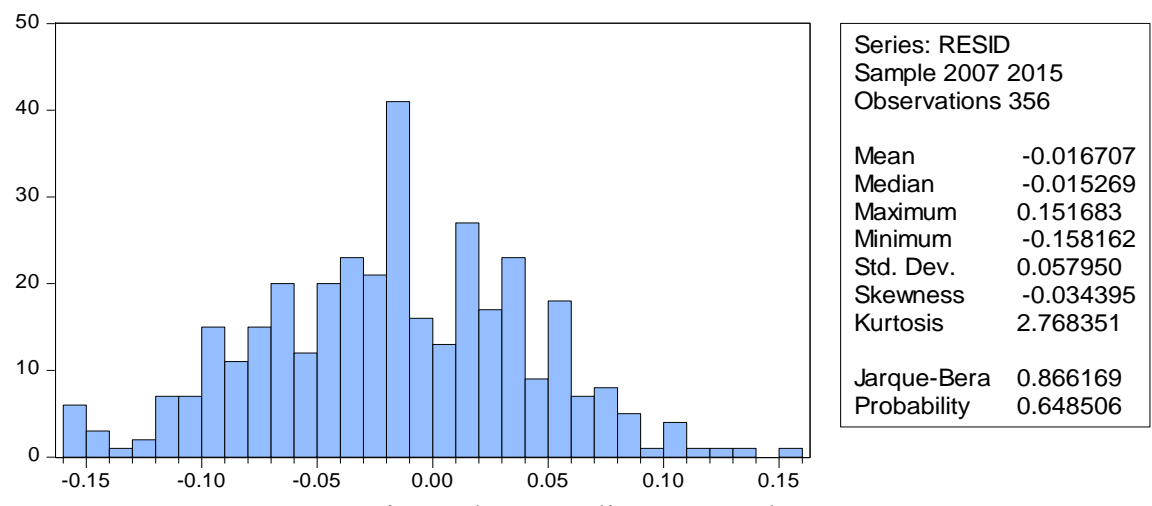

Figure 4. Normality test results

Source: Research Data, 2017.

The null hypothesis under this test is that the residuals are not significantly different from a normal distribution. Given that the p-value was greater than 5\% for the residual, we failed to reject the null hypothesis and thus the conclusion that the residuals are normally distributed. It's clear that the residual were normally distributed and therefore, OLS regression methodology could be applied to estimate the regression models (Brooks, 2008).

\subsubsection{Heteroskedasticity}

The study further conducted Heteroskedasticity test to test the assumption that the residuals have a constant variance (they should be Homoskedastic). The Modified Wald test was used to test for Heteroskedasticity where the null hypothesis of the test is that error terms have a constant variance (i.e. should be Homoskedastic).

Table 1. Test for Heteroskedasticity

.xttest3
Modified Wald test heteroskedasticity
chi2 $(42)=2.4 \mathrm{e}+09$
Prob>chi2 $=0.0000$

Source: Research Data, 2017.

The study failed to reject the null hypothesis given that the reported p-value 0.000 was less than the critical value and thus concluded that the observations have constant variance or do not have the problem of Heteroskedasticity.

\subsubsection{Multicollinearity}

To test for multicollinearity the study used VIF. This study adopted the rule of thumb for VIF value of 10 as the threshold. The VIF values of greater than 10 indicated presence of multicollinearity.

Table 2. Results for Multicollinearity test

\begin{tabular}{lcc}
\hline & Tolerance & VIF \\
\hline Bank Availability & 0.893 & 1.119 \\
Bank Usage & 0.734 & 1.362 \\
Bank Accessibility & 0.711 & 1.407 \\
GDP & 0.247 & 4.051 \\
Credit Risk & 0.348 & 2.87 \\
\hline
\end{tabular}

Source: Research Data, 2017. 
These results indicated that the VIF values of the independent variables were within the threshold of 10 . This indicated that that there was no threat of multicollinearity problem and therefore, the study used linear regression model. The tolerance value was greater than 0.1 ruling out the possibility of multicollinearity (Field, 2009). The result, therefore implied non- existence of a multicollinearity problem among the variable and hence the level of multicollinearity in the model could be tolerated

\subsubsection{Autocorrelation}

The test for autocorrelation was performed to establish whether residuals are correlated across time. Regression analysis assumptions require that residuals should not be correlated across time and thus the Wooldridge test for autocorrelation which is also an LM test was adopted in this study.

Table 3. Results for serial correlation test

\begin{tabular}{l}
\hline Wooldridge test for autocorrelation in panel data \\
\hline H0: no first order autocorrelation \\
$\mathrm{F}(1,38)=0.022$ \\
Prob $>\mathrm{F}=0.8836$
\end{tabular}

The null hypothesis is that no first order serial /auto correlation exists. The results indicated that we failed to reject the null hypothesis that there is no serial autocorrelation of any order and that residuals are not auto correlated ( $\mathrm{p}$-value $=0.8836$ ).

\subsubsection{Panel Unit Root Test}

Panel unit root tests were conducted using the ADF test to establish whether the variables were stationary or non-stationary. The purpose of this was to avoid spurious regression results being obtained by using non-stationary series.

Table 4. Panel unit root test results

\begin{tabular}{lcc}
\hline Variables & ADF-Statistics & Prob \\
\hline Bank Availability & 84.8610 & 0.3339 \\
Bank Usage & 126.579 & 0.0000 \\
Bank Accessibility & 86.6128 & 0.3426 \\
GDP & 142.261 & 0.0000 \\
Credit Risk & 82.4762 & 0.5266 \\
\hline
\end{tabular}

Source: Research Data, 2017.

Results in Table 7 indicated that Bank Usage, and GDP were stationary (i.e. no unit roots) since the p value was less than 0.05 which implied that the null hypothesis that there is a unit root was rejected. Bank Availability, Bank Accessibility, Credit Risk, were non-stationary since their p-values were greater than 0.05 . This therefore, called for first differencing of the non-stationary variables to make them stationary as shown in table 8 .

Table 5. Panel unit root test results at first difference

\begin{tabular}{lcc}
\hline Variables & ADF-Statistics & Prob \\
\hline Bank Availability & 152.921 & 0.0000 \\
Bank Usage & 126.579 & 0.0000 \\
Bank Accessibility & 137.554 & 0.0000 \\
GDP & 142.261 & 0.0000 \\
Credit Risk & 773.669 & 0.0000 \\
\hline
\end{tabular}

Source: Research Data, 2017.

The results in table 8 indicated that all the variables become stationary (unit root disappears) on first differencing since there $\mathrm{p}$ value was less than 0.05 meaning that the study rejected the null hypothesis that there is a unit root.

\subsubsection{Hausman Test for Model Specification}

In order to choose between fixed and random effect model for model 1 credit risk, the Housmas test was used as 
presented in Table 6. The null hypothesis of the Hausman test was that there are no systemic differences between the estimates of the random effect model and the fixed effect model.

Table 6. Hausman test for credit risk

\begin{tabular}{lcccc}
\hline & Fixed $(\mathrm{b})$ & Random $(\mathrm{B})$ & Difference $(\mathrm{b}-\mathrm{B})$ & sqrt(diag(V_b-V_B $))$ S.E. \\
\hline BAV & -2.986118 & -2.986118 & $-7.22 \mathrm{e}-13$ & 0.0410677 \\
BAC & 0.60003 & 0.60003 & $3.36 \mathrm{e}-13$ & 0.00266681 \\
BAU & -0.0227047 & -0.0227047 & $-2.13 \mathrm{e}-12$ & 0.0138897 \\
\hline
\end{tabular}

$\mathrm{b}=$ Consistent under Ho and Ha; obtained from xtreg

$\mathrm{B}=$ Inconsistent under $\mathrm{Ha}$, efficient under Ho; obtained from xtreg

Test Ho: differences in coefficients not systematic

$\left.\operatorname{chi} 2(3)=(b-B) ![\text { V_b-V_B }]^{\wedge}(-1)\right] b-B=9.23$

Prob $>$ chi $2=0.003$

Source: Research Data, 2017.

In Table 6, for credit risk model, the Houseman test reported a chi-square of 9.23 with a p value of 0.003 implying that at 5 percent level, the chi-square obtained was statistically significant. The study therefore failed to reject the null hypothesis of no systematic difference between the estimates of the Random effects model and fixed effects model. Thus the fixed effects model was interpreted as recommended by Green (2008).

\subsection{Test of Hypothesis}

Table 7. Effect of financial inclusion on credit risk- Model 1

\begin{tabular}{lcccc}
\hline Financial inclusion & Coef. & Std. Err. & $\mathrm{t}$ & $\mathrm{P}$ \\
\hline Bank Availability & -2.986118 & 0.117039 & -25.51 & 0.002 \\
Bank Accessibility & 0.060003 & 0.0076037 & 7.89 & 0.0040 \\
Bank Usage & -0.0227049 & 0.0395843 & -0.57 & 0.0026 \\
_cons & 21.96 & 0.927997 & 23.66 & 0.0012 \\
Observations & 369 & & & \\
\hline R-sq: within $=0.8683$ & & & \\
F statistics $=73.132$ & & & \\
Prob $>$ chi2 $=0.0000$ & & & \\
\hline
\end{tabular}

Source: Research Data, 2017.

The results in Table 7 indicate an $\mathrm{R}$ squared of 0.8683 . This implies that the financial inclusion indicators (bank availability, bank accessibility and bank usage) had high explanatory power on bank stability (Measured by Credit Risk). The F statistics value was 73.132 with a $\mathrm{p}$ value of 0.000 which is less than 0.05 . This indicates that financial inclusion had significant effects on the stability of commercial banks in Kenya.

Based on the analysis in Table 7 the following model was formulated.

$$
\text { Credit Risk=21.96-2.986118(BAV)+0.060003(BAC)-0.0227049 (BUS) }+\varepsilon
$$

Model 1

In Table 7 the coefficient of bank availability $(\beta=-2.986118, \mathrm{p}=0.000<0.05)$ shows a statistically significant relationship between bank availability and bank stability. The regression coefficient of -2.986118 obtained in this case implies that a unit increase of the bank availability variable would lead to 2.986118 unit decreases in exposure to credit risk hence increasing stability. The coefficient of accessibility $(\beta=0.060003, p=0.000<0.05)$ shows that the coefficient of bank accessibility in the model is significantly different from zero at five per cent level of significance. This implies that a unit increase in bank accessibility would lead to 0.06003 unit increase in exposure to credit risk. While the coefficient of $(\beta=-0.0227049, \mathrm{p}=0.0026<0.05)$ shows that the coefficient of bank usage in the fixed effect model is significantly different from zero at five per cent level of significance. This implies that a unit increase of bank usage would lead to 0.0227049 unit decrease in exposure to credit risk.

The findings concur with those of Han and Malecky (2013) who established that a greater share of people with bank deposits would increase banks share of stable funding (deposits) and tend to reduce volatility of the bank deposits during economic downturns, thereby contributing to financial stability by reducing the procyclical effects of economic downturns on bank liquidity. 
Table 8. Effect of IFI on credit risk of commercial bank Model 2

\begin{tabular}{lcc} 
& Coefficients & P-Value \\
\cline { 2 - 3 } Constant & 11.4089 & 0.001 \\
IFI & -5.16174 & 0.000 \\
R-Squared & 0.7495 & \\
F statatistic & 81.28 & 0.004 \\
\hline
\end{tabular}

Source: Study Data, 2017.

The results in Table 8 indicate $\mathrm{R}$ squared of 0.7495 for credit risk. This implies that financial inclusion had explanatory power on credit risk as it accounted for 74.95 percent of credit risk of commercial banks in Kenya. This indicates that financial inclusion can adequately explain variation in stability of commercial banks in Kenya. The $F$ statistics value was 81.28 with a $\mathrm{p}$ value of 0.004 which was less than 0.05 . This indicates that financial inclusion was significant in explaining variations in stability of commercial banks in Kenya.

The coefficient of IFI $(\beta=-5.16174, p=0.000<0.05)$ for credit risk shows a statistically significant relationship between financial inclusion and credit risk of commercial banks in Kenya. The findings implied that a unit increase of financial inclusion would lead to 5.16174 decrease in credit risk of commercial banks in Kenya.

Credit Risk $=11.4089-5.16174 * I F I+\varepsilon_{i t}$

Model 2

In the second step, GDP growth rate were introduced as an independent variable. The regression results are presented in Table 9.

Table 9. GDP growth rate as independent variables

\begin{tabular}{lcccc}
\hline Credit risk & Coef. & Std. Err. & t & P \\
\hline IFI & -5.16747 & 0.20851 & -24.75 & 0.008 \\
GDP growth rate & -0.01046 & 0.001919 & -5.45 & 0.403 \\
_cons & 0.277066 & 0.034188 & 8.1 & 0.000 \\
\hline R-sq: within $=0.6819$ & & & & \\
F statistic $=86.93$ & & & \\
p= 0.0005 & & & & \\
\hline
\end{tabular}

Source: Research Data, 2017.

The result in Table 9 indicates an R squared of 0.6819. This implies that financial inclusion and GDP growth rate had high explanatory power on credit risk as they accounted for 68.19 percent of credit risk of commercial banks in Kenya. This indicates that a combination of these variables can adequately explain variation in credit risk.

The F statistics value was 86.93 with a p value of 0.0005 which is less than 0.05 . This indicates that financial inclusion and moderator variables namely GDP growth rate were jointly significant in explaining variations in credit risk and that financial inclusion, and GDP growth rate jointly contributes significantly to changes in the credit risk of commercial banks in Kenya.

The coefficient of IFI $(\beta=-5.16747, p=0.008,>0.05)$ shows a negative statistically significant relationship between IFI and Credit Risk of commercial banks in Kenya. The regression coefficient of -5.16747 obtained in this case implies that a unit increase of the financial inclusion would lead to 5.16747 decreases in credit risk, hence stability.

The coefficient of GDP growth rate at $(\beta=-0.01046, \mathrm{p}=0.403>0.05)$ shows a negative statistically insignificant relationship between GDP growth rate and credit risk. This indicates that GDP growth rate does not directly affect credit risk and thus can moderate the relationship between financial inclusion and credit risk. The regression coefficient of 0.277066 under constant indicates the value of credit risk when financial inclusion, Inflation rate and GDP growth rate were zero. Based on the result in Table 9, the following model was formulated.

$$
\text { Credit Risk=0.277066-5.16747*IFI } I_{i t}-0.01046 G D P_{i t}+\varepsilon_{i t}
$$

Where:

IFI $=$ The Index of Financial Inclusion rate of Bank $i$ at time $t$

GDP $=$ GDP Growth rate of Bank $i$ at time $t$ 
Cons $=$ constan

In the third step, GDP growth rate was introduced as moderator variables. The regression results are presented in Table 10 .

Table 10. GDP growth rate variables as moderators Model 4

\begin{tabular}{lllll}
\hline Credit Risk & Coef. & Std. Err. & t & P \\
\hline IFI & -5.16747 & 0.20851 & -24.75 & 0.000 \\
GDP growth rate & -0.09663 & 0.028927 & -3.34 & 0.032 \\
IFI*GDP growth rate & -0.94854 & 0.28704 & -1.30 & 0.001 \\
_cons & 0.255286 & 0.084022 & 3.04 & 0.002 \\
\hline R-sq: within $=0.6865$ & & & & 0.000 \\
F statistic $=89.24$ & & & & \\
\hline
\end{tabular}

Source: Research Data, 2017.

The result in Table 10 indicates an $\mathrm{R}$ squared of 0.6865 . This implies that when GDP growth rate were introduced as moderators, the model had explanatory power on credit risk as it accounted for 68.65 percent of credit risk of commercial banks in Kenya. This means that a combination financial inclusion and GDP growth rate as moderators can adequately explain variation in credit risk.

The F statistics value was 89.24 with a $\mathrm{p}$ value of 0.000 which is less than 0.05 . This indicates that financial inclusion and GDP growth rate as moderators were jointly significant in explaining variations in credit risk and that financial inclusion and GDP growth rate jointly contributes significantly to changes in the credit risk of commercial banks in Kenya.

The coefficient financial inclusion at $(\beta=-5.16747, p=0.000,<0.05)$ shows a statistically significant relationship between financial inclusion and credit risk of commercial banks. The regression coefficient of -5.16747 obtained in this case implies that a unit increase of the financial inclusion would lead to 5.16747 decreases in credit risk.

The coefficient of GDP growth rate at $(\beta=-0.09663, \mathrm{p}=0.032,<0.05)$ shows a statistically significant relationship between GDP growth rate and credit risk of commercial banks. This indicates that GDP growth rate does directly affect the credit risk of commercial banks and thus can moderate the relationship between financial inclusion and credit risk. The negative coefficient of -0.09663 obtained in this case implies that a unit increase of the GDP growth rate would lead to 0.09663 decreases in credit risk.

Table 10 indicates that when financial inclusion and Inflation rate are interacted, there is a negative and significant relationship and when financial inclusion and GDP growth rate are interacted, there is a negative and significant relationship. The significant interactions imply that Inflation rate and GDP growth rate affect the credit risk of commercial financial inclusion.

The regression coefficient of 0.255286 under constant indicates the value of credit risk when financial inclusion, Inflation rate and GDP growth rate as moderator variable were zero. Based on the result in Table 10, the following model was formulated

$$
\text { Credit Risk }=0.255286-5.16747 * I F I_{i t-} 0.09663 G D P_{i t} 0.94854 I F I^{*} G D P+\varepsilon_{i t}
$$

Model 4

Where:

IFI = The Index of Financial Inclusion rate of Bank $i$ at time $t$

$\mathrm{GDP}=\mathrm{GDP}$ Growth rate of Bank $\mathrm{i}$ at time $\mathrm{t}$

Cons $=$ constants

Therefore, the coefficient of IFI in model 2 was statistically significant implying that there exists a significant relationship between financial inclusion and credit risk In model 3 GDP is not an explanatory variable for credit risk, the findings in model 4 imply that GDP is a moderator whose sign and magnitude is given by the coefficient of the interaction term. Therefore, GDP is a moderator that enhances the effect of financial inclusion on credit risk by 0.949 per cent. The findings are supported by Mostak and Sushanta, 2015 who observed that financial inclusion coincides with increase in economic growth.

\section{Conclusions}

The study sought to examine the effect of financial inclusion on credit risk of commercial banks. Panel yearly 
data from 2007-2015 was used employing a panel multiple regression analysis model. To achieve the objective, the explanatory variable financial inclusion was measured using the three dimensions of financial inclusiveness of a system including bank availability, bank accessibility and bank usage. The dependent variable was bank credit risk which was represented by non performing loans ratio.

The study analysed the trends in financial inclusion including bank availability, bank accessibility and bank usage for commercial banks in Kenya and revealed commercial banks in Kenya increased financial inclusion from the 2006 to 2015. This was a clear indication of the increase of bank accessibility due to increase in the number of commercial banks and increase in branch network of the major banks which lead to more Kenya opening accounts with the commercial Banks.

The stability indicators of credit risk, showed constant credit risk exposure with a slight drop in 2014. This implied that commercial banks exopsure to credit risk was minimum in 2014. The finding showed that exposure to credit risk increased in 2015 which coincided with the collapse of a number of commercial banks in Kenya.

The study further employed panel multiple regression to ascertain the relationship between financial inclusion measured by availability, accessibility and usage and bank credit risk measured by non performing loans ratio which was the dependent variables in this study. Bank availability was found to have a negative significant effect on credit risk. This implies that bank availability reduces credit risk attributed to better stability. Bank accessibility was found to have a positive significant effect on credit risk meaning it increases non performing loans hence posing a stability threat. While bank usage was found to have a negative significant effect on credit risks. GDP growth rate was found to significantly moderate the relationship between financial inclusion and credit risk of commercial banks in Kenya.

\section{Recommendations}

Based on the findings of this study, the following recommendations were made; Banks should find ways of improving the level of financial inclusion by expanding on dimensions of penetration such as bank availability, bank accessibility and bank usage by using channels easily used by all and coming up with product that are readily accepted to increase usage. The study also recommended that commercial banks in Kenya should plead with Central Bank and Ministry of Finance to put measures of addressing macroeconomic fundamentals especially GDP, which influences the level of financial inclusion and credit risk. Formal financial institutions should relax the requirements for opening and holding an account with them in order to facilitate the low income group to access prior financial services. Also the governments could consider providing financial literacy among the population to enable them utilize financial services for the welfare of both countries' financial system and users.

\section{Referrences}

Adasme, O., Majnoni, G., \& Uribe, M., (2006). Access and risk: friends or foes? Lessons from Chile. Policy Research Working Paper 4003, World Bank, Washington, D. C. https://doi.org/10.1596/1813-9450-4003

Aduda, J., \& Kalunda, E. (2012). Financial inclusion and financial sector stability with reference to Kenya: A preview of literature. Retrieved from https://EconPapers.repec.org/RePEc:spt:apfiba:v:2:y:2012:i:6:f:2_6_8

Adusei, M., \& Elliott, C. (2015). The impact of bank size and funding risk on bank stability in Ghana. Cogent Economics \& Finance, 3(1), 1111489. https://doi.org/10.1080/23322039.2015.1111489

Allen, F., Carletti, E., Cull, R., Qian, J., Senbet, L.W., \& Valenzuela, P. (2013). Improving access to banking: Evidence from Kenya. World Bank Policy Research Working Paper No. 6593. https://doi.org/10.1596/1813-9450-6593

Amatus, H., \& Alireza, N. (2015) Financial inclusion and financial stability in Sub-Sahara Africa (SSA). International Journal of Social Sciences. Retrieved from https://www.tijoss.com/TIjoss\%2036th\%20Volume/5Amatus.pdf

Bartha, J. R., Caprio, G., \& Levin, R. (2008). Bank regulations are changing: For better or worse \& Quest. Comp. Econ., 89, 285-296. https://doi.org/10.1596/1813-9450-4646

Beck, Demirguc-Kent, \& Peria. (2006). Banking services for everyone? Barriers to bank access and use around the world. World Bank Working Paper 4079. https://doi.org/10.1596/1813-9450-4079

Beck, T. (2009). Fin Access 2009: Trends, Analysis and Policy Conclusions. Consultant report for FSD Trust Kenya.

Beck, T. (2013). Cross border banking and financial deepening: The African experience. Paper presented at an 
$\begin{array}{lllll}\text { AERC workshop } & \text { December } & \text { Retrieved } & \text { from }\end{array}$ https://academic.oup.com/jae/article-pdf/24/suppl_1/i32/7502815/eju028.pdf

Beck, T., De Jonghe, O., \& Schepens, G. (2013). Bank competition and stability: Cross-country heterogeneity. J. Financ. Intermed., 22, 218-244. https://doi.org/10.1016/j.jfi.2012.07.001

Beck, T., Demirgüç-Kunt, A., \& MartínezPería, M. S. (2011). Bank financing for SMEs: Evidence across countries and bank ownership types. J. Financ. Serv. Res., 39, 35-54. https://doi.org/10.1007/s10693-010-0085-4

Carneiro, F. L. (2011). Is there evidence of a trade-off between financial stability and efficiency of financial intermediation? Preliminary insights from the global financial crisis of 2007-2009. Retrieved from https://programs.wcfia.harvard.edu/files/fellows/files/carneiro.pdf

CBK. (2009). Financial Access Partnership. FAB Survey.

CBK. (2013). Financial Access Partnership. FAB Survey.

Central Bank of Kenya. (2013). Retrieved from http://website:www.centralbankofkenya.go.ke

Central Bank of Kenya. (2014). Bank Supervision Annual Report. Nairobi, Kenya: Central Bank of Kenya.

Central Bank of Kenya. (2015). Bank Supervision Annual Report. Nairobi, Kenya: Central Bank of Kenya.

Chibba, M. (2009). Financial inclusion poverty reduction and the millennium development goals. European Journal of Development Research, 230. https://doi.org/10.1057/ejdr.2008.17

Ciha'ki, M., Mare, D., \& Malecky, Y. (2016). The nexus of financial inclusion and financialstability. World Bank working paper 7722 .

Demirgüç-Kunt, A., \& Huizinga, H. (2010). Bank activity and funding strategies: The impact on risk and returns. J. Finance. Econ., 98, 626-650. https://doi.org/10.1016/j.jfineco.2010.06.004

Demirgüç-Kunt, A., Klapper, L., \& Singer, D. (2013). Financial inclusion and legal discrimination against women: Evidence from developing countries. World Bank Policy Research Working Paper. Retrieved from https://openknowledge.worldbank.org/handle/10986/15553

Demirgüç-Kunt, A., Klapper, L., Singer, D., \& Van Oudheusden, P. (2015). The Global Findex Database 2014: Measuring Financial Inclusion around the World. World Bank Policy Research Working Paper 7255. Retrieved from https://www.openknowledge.worldbank.org/handle/10986/21865

Demirguc-Kunt, Beck, T., \& Honohan, P. (2008). Finance for all Policies and Pitfalls in expanding access. World Bank Policy Research report, Washington. Retrieved from https://openknowledge.worldbank.org/handle/10986/6905

Demirgut-kunt, A., \& Klapper, L. (2012). Measuring Financial Inclusion: The Global Findex Database. Policy Research working paper 6025, World Bank, Washington DC. Retrieved from https://www.openknowledge.worldbank.org/handle/10986/21865

Diniz, D., Rene, B., \& Marlei, P. (2011). Triggers and barriers to financial inclusion. The use of ICT-based branchless banking in an Amanon country. Electronic Commerce Research and Application, 11, 484-494. Retrieved from https://www.researchgate.net/.../251693480_Triggers_and_barriers_to_financial_inclusi

Financial Sector Deepening Kenya (FSDK). (2013). Fin Access National Survey 2013.

Government of Kenya. (2007). Kenya Vision 2030.

Gujarati, D. (2003). Basic Econometrics (4th ed., pp. 638-640). New York: McGraw Hill.

Han, R., \& Melecky, M. (2013). Financial inclusion for financial stability: Access to bank deposits and the growth of deposits in the global financial crisis. World Bank Policy Research Working Paper. Retrieved from https://www.openknowledge.worldbank.org/handle/10986/16010

Hannig, A., \& Jansen, S. (2010). Financial inclusion and financial stability: Current policy issues. Retrieved from https://www.adb.org/sites/default/files/publication/156114/adbi-wp259.pdf

Honohan, P. (2008). Cross-country variation in household access to financial services. J. Bank. Finance, 32, 2493-2500. https://doi.org/10.1016/j.jbankfin.2008.05.004

Kalunda, E. N. (2015). Financial inclusion, bank stability, bank ownership and financial performance of commercial banks in Kenya. 
Kenya bankers association. (2012). Growth of the bank sector in Kenya. Nairobi: Government press. Retrieved from https://www.bis.org/review/r120822b.pdf

Kenya. (2007). Kenya Vision 2030. The popular version, Nairobi. Retrieved from http://www.vision2030.go.ke

Kenya. (2013). Kenya vision 2030: Second medium Term plan 2013-2017, Nairobi. Retrieved from http://www.vision2030.go.ke

Khan, H. (2011). Financial Inclusion and Financial Stability: Are they two sides of the same coin? Speech at Bancon. Retrieved from https://www.bis.org/review/r111229f.pdf

Matete, J. K. (2014). Factors Affecting Pricing of Loanable Funds by Commercial Banks in Kenya. International Journal for Business and Social Science, 244-245.

Morgan, P., \& Pontines, V. (2014). Financial Stability and Financial Inclusion. Asian Development Bank Institute. ADBI Working Paper 488. https://doi.org/10.2139/ssrn.2464018

Mostak, M., \& Sushanta, M. (2015). Is financial inclusion good for bank stability? International evidence. University of London, U.K. Retrieved from https://editorialexpress.com/cgi-bin/conference/download.cgi?db_name...paper

Ngugi, D. (2015). Relationship between mobile banking and financial inclusion in Kenya (Unpublished MBA Project University of Nairobi).

Ongore, V. O., \& Kusa, G. B. (2013). Determinants of Financial performance of commercial banks in Kenya. International Journal of Economics and Financial Issues, 237-238.

Sahrawat, R. (2010). Financial inclusion from obligation to opportunity. Tata Consultancy Services LTD.

Sarma, \& Pias. (2011). Financial inclusion and development: A cross country Analysis. Journal of Economic Literature (JEL). https://doi.org/10.1002/jid.1698

Sarma, M. (2007). Index of financial inclusion. India council of research on international Economic Relations, Delhi, November 2007.

Sarma, M. (2008). Index of financial inclusion. Indian council for research on international Economic Relations, Delhi, June 2008.

Sarma, M., \& Pais, J. (2012). Financial inclusion and development. Journal of International Development, 23, 613-628. https://doi.org/10.1002/jid.1698

\section{Copyrights}

Copyright for this article is retained by the author(s), with first publication rights granted to the journal.

This is an open-access article distributed under the terms and conditions of the Creative Commons Attribution license (http://creativecommons.org/licenses/by/4.0/). 